\title{
Effect of Chemical Reclamation on the Physiological and Chemical Response of Rice Grown in Varying Salinity and Sodicity Conditions
}

\author{
Ayesha Abdul Qadir ${ }^{1}$, Ghulam Murtaza ${ }^{1 *}$, M Zia-ur-Rehman ${ }^{1}$ and Ejaz Ahmad Waraich ${ }^{2}$ \\ ${ }^{1}$ Institute of Soil and Environmental Sciences, University of Agriculture, Faisalabad-38040, Pakistan \\ ${ }^{2}$ Department of Agronomy, University of Agriculture Faisalabad, Pakistan \\ "For correspondence: gmurtazauaf@gmail.com \\ Received 01 March 2021; Accepted 17 April 2021; Published 10 June 2021
}

\begin{abstract}
Salinity and sodicity are the major abiotic constraints that prevail in arid and semi-arid regions. Proper management is required for productive use of this land. Reclamation of sodic and saline-sodic soils is highly site-specific that describes the diverse response of different soils to different amendments. These reclamation practices also alter the plant's physiological and ionic characteristics. This experiment aimed to better understand the physiological and ionic responses of rice crop at different salinity/sodicity levels. A lysimeter experiment was set forth with soil having $\mathrm{EC}_{\mathrm{e}}\left(\mathrm{dS} \mathrm{m}^{-1}\right): \mathrm{SAR}\left(\mathrm{mmol} \mathrm{L}^{-1}\right)^{1 / 2}$ levels as 4:20, 8:40, 12:60 and 16:80 and all the levels were treated with organic (farm manure at $25 \mathrm{Mg} \mathrm{ha}^{-1}$ ) and inorganic (gypsum at $100 \%$ soil gypsum requirement (SGR) and sulphuric acid equivalent to $100 \%$ SGR) amendments keeping no ammendment as control. Results revealed that the maximum relative increase in physiological attributes (photosynthetic rate, transpiration rate, stomatal conductance and total chlorophyll contents), ionic contents (nitrogen, potassium and K:Na ratio) and growth of rice were recorded with sulphuric acid application followed by gypsum. On an average $25 \%, 31 \%$ and $45 \%$ increase in biological yield, plant height and paddy yield, respectively was observed with sulphuric acid application over control. It is concluded that sulphuric acid and gypsum both were the best amendments for reclamation of soil having a low level of salinity/sodicity whereas, at higher salinity/sodicity levels, only sulphuric acid seemed better for improved rice production. () 2021 Friends Science Publishers
\end{abstract}

Keywords: Rice; Gas exchange attributes; Salinity; Sodicity; Amendments; Reclamation

\section{Introduction}

The excess of soluble salts in agricultural land leads to soil salinity and the conditions become more severe when sodicity (a high amount of exchangeable sodium $\left(\mathrm{Na}^{+}\right)$) prevails, which not only disturbs the nutrient dynamics but also degrade the soil structure. Soil salinity and sodicity are two of the world's most important soil issues, especially in arid and semi-arid regions. Around the globe, above $8 \times 10^{8}$ ha of land is salt degraded either by salinity $\left(3.4 \times 10^{8} \mathrm{ha}\right)$ or sodicity $\left(5.6 \times 10^{8}\right.$ ha) (Shahid et al. 2018). Salt degraded area of Asia $\left(194.7 \times 10^{6}\right.$ ha of saline and $121.9 \times 10^{6}$ ha of sodic) accounts for about $33.9 \%$ of the world's salt-affected land (Shahid et al. 2018). According to the estimate of Qadir et al. (2014), negative impacts of salt-affected irrigated land on crop production could cost the global economy about US\$ 27.3 billion annually. In Pakistan, $10 \times$ $10^{6}$ ha area is currently affected due to salinity and sodicity and is growing rapidly (Shahid et al. 2018).

Mostly the salinity and sodicity exist together in soil which means the stress of both soluble salts and exchangeable $\mathrm{Na}^{+}$in a medium. Salinity combined with sodicity is more harmful to plant growth than salinity alone (Abbas et al. 2021). These soils have less organic matter, a disturbed soil structure, and a lower water holding capability. Disorganized aggregate formation in these degraded soils affects soil water, nutrients, and plant development (Nan et al. 2016; Abbas et al. 2021). The deleterious effects of soil salinity/ sodicity are dependent upon the type and period of salt-affected soil. Moreover, plant species and their genetic makeup also play a remarkable role (Ata-Ul-Karim et al. 2016; Liu et al. 2020; Riaz et al. 2020).

Soil salinity and/or sodicity induce ion toxicity and osmotic stress, and crust formation affects plant by delaying germination (Ata-Ul-Karim et al. 2016). Plant growth mechanisms such as photosynthesis, stomatal conductance, nutrient balance and metabolic functions are all affected by salinity and sodicity (Nam et al. 2018; Zahra et al. 2018). The high concentration of $\mathrm{NaHCO}_{3} / \mathrm{Na}_{2} \mathrm{CO}_{3}$ under sodic conditions results in increased $\mathrm{pH}(>8.5)$ that negatively influences nutrient uptake in plants (Liu et al. 2020). The

To cite this paper: Qadir AA, G Murtaza, M Zia-ur-Rehman, EA Waraich (2021). Effect of chemical reclamation on the physiological and chemical response of rice grown in varying salinity and sodicity conditions. Intl J Agric Biol 26:97-104 
imbalance of nutrients (excess of $\mathrm{Na}^{+}$) in plants deteriorates the normal growth process and ultimately leads to abnormal cell functioning and plant death (Quintero et al. 2007).

Among the monocot crops, rice (Oryza sativa L.) is considered salt sensitive whereas, its tolerance level varies with genotypes because of additive gene effects (Abbas et al. 2013; Hussain et al. 2018; Sardar et al. 2018). In the world, $7.55 \times 10^{8} \mathrm{t}$ rice has been produced in the year 2018-19 from the total harvested area of $1.62 \times 10^{8}$ ha with a $4.64 \mathrm{t} \mathrm{ha}^{-1}$ yield. Asia is the biggest rice producer and consumer and accounts for $92 \%$ of the world's rice production. In the year $2019,11.11 \times 10^{6} \mathrm{t}$ rice was produced from $3.03 \times 10^{6}$ ha in Pakistan (FAO 2020). Qadir et al. (2014) reported 36-69\% grain yield losses in rice crop due to salinity and sodicity in comparison with their counterpart normal soils in Pakistan.

Adopting appropriate diagnosis, reclamation, and land-water management approaches can help to restore and cultivate these problematic soils and play a significant role in efficient soil and water conservation. For many decades, chemical amendments have been used for the reclamation of salt-affected soils (Kheir et al. 2018; Singh et al. 2018; Zhou et al. 2019). The most commonly used inorganic amendments include gypsum (Rasouli et al. 2013; Gonçalo et al. 2020) and sulphuric acid (Mahmoodabadi et al. 2013; Kheir et al. 2018). Organic amendments, such as farm manure can also be used for the reclamation of salt-affected soils (Ahamed et al. 2019; Leogrande and Vitti 2019).

Amelioration of sodic and saline-sodic soils is highly site-specific and illustrates how different soils react to different amendments. Many scientists have noted the effectiveness of one amendment over another in the context of a single environment (Kheir et al. 2018; Day et al. 2019). Despite this, the comparison of different responses of organic and inorganic amendments towards different soil salinity/sodicity situations requires more investigation in a broad spectrum. According to our understanding, no comprehensive study was conducted to evaluate crop ionic and physiological activity changes during the reclamation of sodic and saline-sodic soils using various organic and inorganic amendments. Therefore, this experiment was executed to understand the physiological and ionic responses of rice crop at specific salinity/sodicity levels under the application of different organic and inorganic amendments. Additionally, screening of appropriate amendments for the amelioration of soils with different $\mathrm{EC}_{\mathrm{e}}$ :SAR levels for growing rice crop was also done.

\section{Materials and Methods}

\section{Collection of soils and amendments}

Soils used in this experiment were collected from the naturally degraded and uncultivated area, Village No. 132/GB (73 0653, 31 1903$)$, located near Dijkot district Faisalabad, Pakistan. Bulk of topsoil $(0-20 \mathrm{~cm})$ was collected from 2 different points of barren land. The collected soil samples were ground, mixed thoroughly, sieved through a $2 \mathrm{~mm}$ stainless steel sieve and prepared for physicochemical analysis $\left(\mathrm{EC}_{\mathrm{e}}, \mathrm{pH}_{\mathrm{s}}\right.$, soluble cations and anions) following the procedure described by US Salinity Lab. Staff (1954). These soils have variable $\mathrm{EC}_{\mathrm{e}}$ and SAR (normal and saline-sodic soil) but have the same textural class (sandy clay loam). The normal soil had $\mathrm{EC}_{\mathrm{e}}=4.01 \mathrm{dS}$ $\mathrm{m}^{-1}, \mathrm{SAR}=8.17\left(\mathrm{mmol} \mathrm{L}^{-1}\right)^{1 / 2}, \mathrm{pH}_{\mathrm{s}}=7.44, \mathrm{CaCO}_{3}=4.80 \%$, organic matter $=0.43 \%$ and $\mathrm{CEC}=9.8 \mathrm{cmol}_{\mathrm{c}} \mathrm{kg}^{-1}$. The saline-sodic soil had $\mathrm{EC}_{\mathrm{e}}=23.5, \mathrm{dS} \mathrm{m}{ }^{-1}, \mathrm{SAR}=87.5(\mathrm{mmol}$ $\left.\mathrm{L}^{-1}\right)^{1 / 2}, \mathrm{pH}_{\mathrm{s}}=8.1$. Amendments, i.e., Farm manure (FM) was collected from the dairy farm of the University of Agriculture, Faisalabad. The basic characteristics of FM were: $\mathrm{EC}_{1: 10}=4.75 \mathrm{dS} \mathrm{m}{ }^{-1}, \mathrm{pH}$ of 7.2, total carbon (dry weight basis $)=42 \%$, a total nitrogen (dry weight basis) $=$ $1.75 \%, \mathrm{Na}^{+}=1.28 \%, \mathrm{~K}^{+}=2.45 \%$. The $\mathrm{FM}$ was air-dried and ground to a fine powder before application. Gypsum ( $80 \%$ pure) was purchased from a local fertilizer supplier and commercial grade sulphuric acid (98\%) was procured from a local scientific store.

\section{Experimental setup}

The experiment was carried out in lysimeters using soils with varying salinity/sodicity at wire-house of Institute of Soil and Environmental Sciences, University of Agriculture, Faisalabad, using rice as a test crop. The metrological conditions of experimental region during this crop season were ranged as temperature min 20 and max $31^{\circ} \mathrm{C}$, relative humidity $51-62 \%$, maximum rainfall 48 $\mathrm{mm}$ and sunshine 6-7 h.

Soils with varying salinity/ sodicity are described as $\mathrm{EC}_{\mathrm{e}}\left(\mathrm{dS} \mathrm{m} \mathrm{m}^{-1}\right): \mathrm{SAR}\left(\mathrm{mmol} \mathrm{L}^{-1}\right)^{1 / 2}$ levels. Different $\mathrm{EC}_{\mathrm{e}}: \mathrm{SAR}$ levels 4:20, 8:40, 12:60 and 16:80 were developed by mixing different proportions of normal and saline-sodic soil. Normal and saline-sodic soils were mixed for each level separately at different proportions keeping in view their original $\mathrm{EC}_{\mathrm{e}}$ and $\mathrm{SAR}$ value (Table 1). Polyvinyl chloride lysimeters (internal diameter $26 \mathrm{~cm}$ and $64 \mathrm{~cm}$ long) were filled with $42 \mathrm{~kg}$ soil after developing designed $\mathrm{EC}_{\mathrm{e}}: \mathrm{SAR}$ levels of soil. Four lysimeters in triplicate sets of each $\mathrm{EC}_{\mathrm{e}}: \mathrm{SAR}$ level were maintained. Amendments including gypsum (G) at $100 \%$ soil gypsum requirement (SGR), sulphuric acid (SA) equivalent to $100 \%$ SGR and farm manure (FM) at $25 \mathrm{Mg} \mathrm{ha}^{-1}$ were applied at each level of $\mathrm{EC}_{\mathrm{e}}: \mathrm{SAR}$ and one control (without addition of any amendment) were kept along. There were 16 treatments and 48 experimental units in total.

Seeds of rice cultivar 'Super Basmati' were sown in normal soil and after 35 days, seedlings were transplanted in soil-filled lysimeters maintaining four plants per lysimeter. The recommended dose of N:P:K (55:45:32.5 mg kg-1) nutrients (using urea, diammonium phosphate and sulphate of potash) was applied. The full dose of $\mathrm{P}, \mathrm{K}$ and $1 / 3^{\text {rd }}$ of the recommended dose of $\mathrm{N}$ was applied at the time of transplanting and the remaining $\mathrm{N}$ was applied in two equal 
splits at tillering and reproductive stages. Throughout the growth period of crop, canal water having EC $0.25 \mathrm{dS} \mathrm{m}^{-1}$, total soluble salts $2.5 \mathrm{mg} \mathrm{L}^{-1}$, SAR $1.38\left(\mathrm{mmol} \mathrm{L}^{-1}\right)^{1 / 2}$ and RSC Nil, was used for irrigation as per crop requirement. After 40 days of transplanting rice seedlings, gas exchange attributes, i.e., photosynthetic rate, transpiration rate and stomatal conductance were recorded using a portable narrow chambered infrared gas analyzer (IRGA, LCA-4, Analytical Development Company, Hoddesdon, England). Leaf total chlorophyll content index of fully expanded leaves of 40 days old plants were determined via SPAD-502 meter (Minolta, Osaka, Japan). Average SPAD readings were recorded from three measurements following Saqib et al. (2012). At maturity, the crop was harvested and different plant growth parameters (plant height, biological yield and paddy yield) were recorded. Plant samples were safely set aside for ionic analysis. After harvest, soil samples were collected from lysimeters for analysis.

\section{Plant digestion and nutrient analysis}

Harvested plant samples were washed and set in paper bags separately. These bags were placed in a drying oven at $70^{\circ} \mathrm{C}$ and dried till the constant weight was achieved. After grinding these plant samples (straw and paddy) in Wiley mill fitted with stainless steel blades, were digested. Di-acid mixture $\left(\mathrm{HNO}_{3}: \mathrm{HClO}_{4}\right.$ 2:1 v/v) was used for this purpose. After digestion, the filtrate was stored in air-tight bottles. Total $\mathrm{N}$ in straw and paddy was determined by microKjeldahl method (Isaac and Johnson 1976). Total P of plant samples was measured on a UV-visible spectrophotometer (Thermo Electron, Waltham, U.S.A.) after standardizing the instrument with $\mathrm{KH}_{2} \mathrm{PO}_{4}$ solutions of known concentration. Total $\mathrm{Na}$ and $\mathrm{K}$ were analyzed by Jenway PFP-7 flame photometer using standard curve drawn by running the solutions of known concentration (prepared using reagent grade $\mathrm{NaCl}$ and $\mathrm{KCl}$ ) on the instrument.

\section{Soil analysis}

The post-rice harvest soil samples were collected from lysimeters by using stainless steel sampling tube. Collected samples were air-dried, ground to pass through a $2 \mathrm{~mm}$ sieve and stored in plastic bags. These samples were analysed for $\mathrm{pH}_{\mathrm{s}}, \mathrm{EC}_{\mathrm{e}}$ and soluble cations following the methods described by the US Salinity Lab. Staff (1954).

\section{Statistical analysis}

Experiment was laid out in a factorial completely randomized design (Factor 1: $\mathrm{EC}_{\mathrm{e}}: \mathrm{SAR}$ levels and Factor 2: Amendments) with three replications. The data were presented as mean values and the standard errors were calculated using Microsoft Excel software. The statistical analyses of data were done using Statistix v. 8.1 computer software. Analysis of variance (two-way ANOVA) and subsequent pairwise comparison was done with Tukey's HSD test at 5\% probability. Radar diagrams were drawn using Origin software (v. 2019, U.S.A.) by putting relative values of plant physiological data.

\section{Results}

\section{Physiological changes in response to applied amendments at various $\mathrm{EC}_{\mathrm{e}}: \mathrm{SAR}$ levels}

Rice physiological parameters such as photosynthetic rate $(A)$, transpiration rate $(E)$, stomatal conductance $(g s)$ and total chlorophyll content (SPAD) were significantly influenced by the $\mathrm{EC}_{\mathrm{e}}$ :SAR levels and the type of amendment used, as well as their interaction. The maximum relative increase in SPAD, $A, E$ and $g s$ was observed with SA at all ECe:SAR levels except ECe:SAR level 12:60 (Fig. 1). All the recorded physiological data indicated that the increase in $\mathrm{EC}_{\mathrm{e}}: \mathrm{SAR}$ levels results in gradual or sharp decrease in SPAD, $A, E$ and $g s$ values. The gradual decrease was observed in SPAD and $A$ whereas $E$ and $g_{s}$ depicted a sharp decrease at $\mathrm{EC}_{\mathrm{e}}: \mathrm{SAR}$ level 8:40 and then decrease gradually with increasing $\mathrm{EC}_{\mathrm{e}}$ :SAR levels (Fig. 1e).

\section{Growth variations in response to applied amendments at various $\mathrm{EC}_{\mathrm{e}}: \mathrm{SAR}$ levels}

As shown in Fig. 2, the biological yield, plant height and paddy yield were significantly affected with increasing $\mathrm{EC}_{\mathrm{e}}: \mathrm{SAR}$ levels and type of applied amendment and their interaction. Sulphuric acid depicted maximum values for biological yield, plant height and paddy yield whereas the amendments follow the following sequence in increasing rice growth; $\mathrm{SA}>\mathrm{G}>\mathrm{FM}>\mathrm{C}$. The maximum increase in biological yield (37.68\% relative to control) was observed at $\mathrm{EC}_{\mathrm{e}}$ :SAR level 4:20 with SA. Considering plant height, SA remained best amendment at all $\mathrm{EC}_{\mathrm{e}}: \mathrm{SAR}$ levels with the maximum relative increase of $43.76 \%$ at $\mathrm{EC}_{\mathrm{e}}: \mathrm{SAR}$ level 4:20 followed by $40.96 \%$ at $\mathrm{EC}_{\mathrm{e}}: \mathrm{SAR}$ level 16:80 with respect to control. The paddy yield varies between 0.97 to $3.86 \mathrm{~g} \mathrm{plant}^{-1}$ with maximum value at $\mathrm{EC}_{\mathrm{e}}$ :SAR level 4:20 and minimum value at level 16:80

\section{Ionic variations in response to applied amendments at} various $\mathrm{EC}_{\mathrm{e}}: \mathrm{SAR}$ levels

Nitrogen: Nitrogen $(\mathrm{N})$ concentration in straw and paddy was significantly influenced with $\mathrm{EC}_{\mathrm{e}}: \mathrm{SAR}$ levels, type of amendment and their interaction. In straw, $\mathrm{N}$ concentration varied between 0.40 and $0.65 \%$, with maximum concentration at $\mathrm{EC}_{\mathrm{e}}: \mathrm{SAR}$ level $12: 60$ and minimum at $\mathrm{EC}_{\mathrm{e}}$ :SAR level 4:20 (Table 2). A promising increase in $\mathrm{N}$ was observed with SA (24 to $36 \%$ with respect to respective controls) at all $\mathrm{EC}_{\mathrm{e}} \mathrm{SAR}$ levels. In case of paddy, the maximum value $(1.11 \%)$ was recorded with $\mathrm{G}$ at $\mathrm{EC}_{\mathrm{e}}$ :SAR level 12:60 and the minimum $(0.72 \%)$ was observed with control at $\mathrm{EC}_{\mathrm{e}}: \mathrm{SAR}$ level 16:80 (Table 2). 

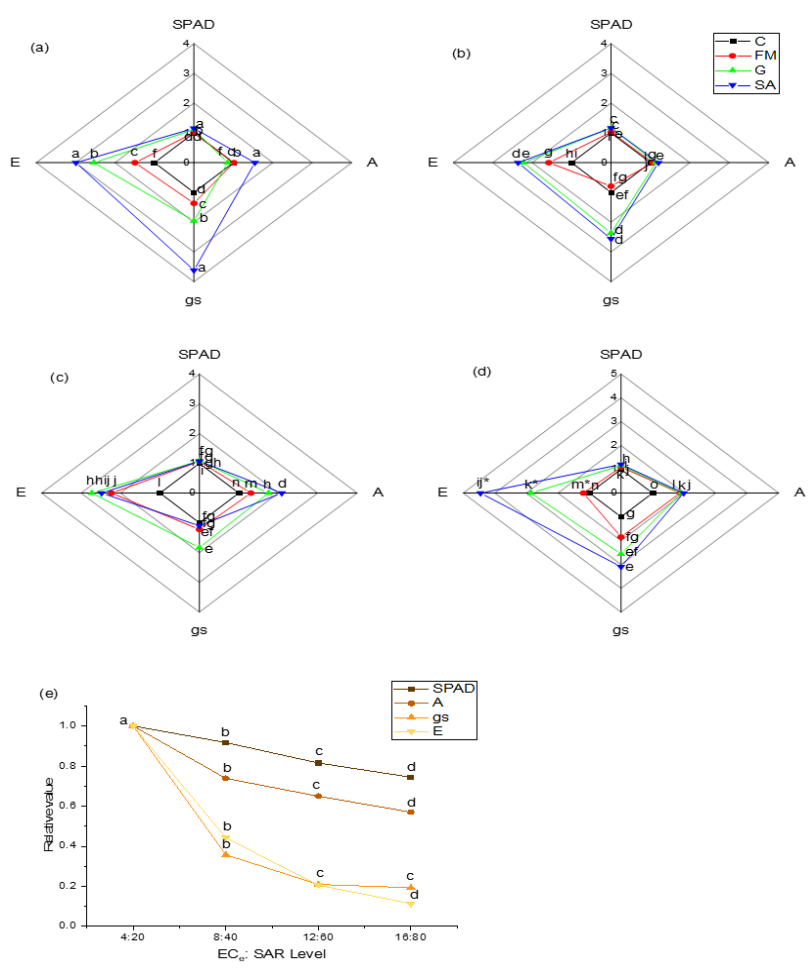

Fig. 1: Radar charts representing variation in physiological parameters of rice due to $\mathrm{EC}_{\mathrm{e}}$ : SAR level a) 4:20, b) 8:40, c) 12:60 and d) 16:80. The status of physiological parameters with FM (red), G (green) and SA (blue) is shown relative to the control $(\mathrm{C}=$ black $)$. e) Line chart representing the relative effect of $\mathrm{EC}_{\mathrm{e}}$ : SAR levels on physiological parameters. $*=$ value is presenting as divisor of $4 . \mathrm{C}=\mathrm{Control} ; \mathrm{FM}=$ Farm manure at 25 $\mathrm{Mg} \mathrm{ha}{ }^{-1} ; \mathrm{G}=$ Gypsum at $100 \%$ SGR; SA= Sulphuric acid equivalent to $100 \% \mathrm{SGR}$. SPAD $=$ Total chlorophyll contents, $\mathrm{A}=$ Photosynthetic rate, gs= Stomatal conductance and $\mathrm{E}=$ Transpiration rate

Common alphabets above points at an antenna represents non-significant difference at $P \leq 0.05$

Phosphorus: The straw phosphorus (P) concentration shows a variable trend with respect to both $\mathrm{EC}_{\mathrm{e}}: \mathrm{SAR}$ level and amendments (Table 2). However, the studied factors and their interaction have a significant effect. The $\mathrm{P}$ concentration in rice straw was ranged from 0.10 to $0.03 \%$. The maximum relative increase in straw $\mathrm{P}$ concentration was observed with FM at $\mathrm{EC}_{\mathrm{e}}$ :SAR level 8:40 and 12:60. Paddy $\mathrm{P}$ concentration was significantly varied with different $\mathrm{EC}_{\mathrm{e}}: \mathrm{SAR}$ levels and amendments. The maximum $\mathrm{P}$ concentration in paddy was observed with $\mathrm{SA}$ at $\mathrm{EC}_{\mathrm{e}}$ :SAR level 4:20 whereas, $G$ showed better results at levels 8:40 and 12:60. At $\mathrm{EC}_{\mathrm{e}}: \mathrm{SAR}$ level 16:80, FM performed best regarding paddy $\mathrm{P}$ concentration.

K:Na ratio: There was a significant variation in straw and paddy potassium:sodium ratio ( $\mathrm{K}: \mathrm{Na}$ ratio) due to $\mathrm{EC}_{\mathrm{e}}: \mathrm{SAR}$ levels, applied amendments and their interaction (Table 2). In straw, K:Na ratio varied between 0.42 and 3.58 whereas in paddy, values for $\mathrm{K}: \mathrm{Na}$ ratio lies between 0.72 and 6.23 .
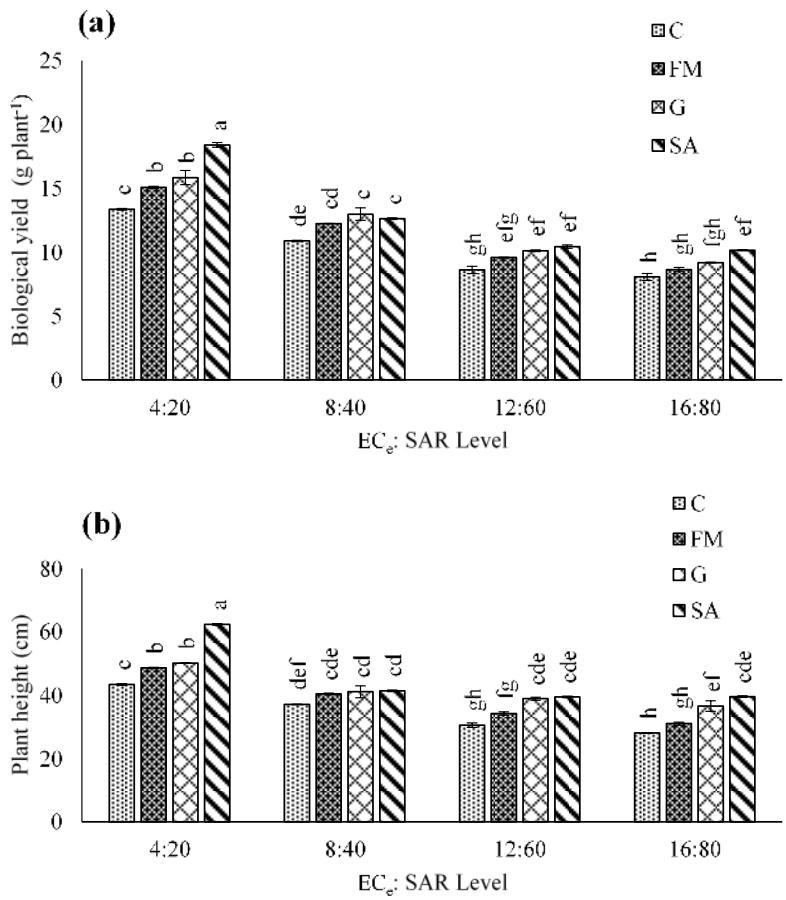

(c)

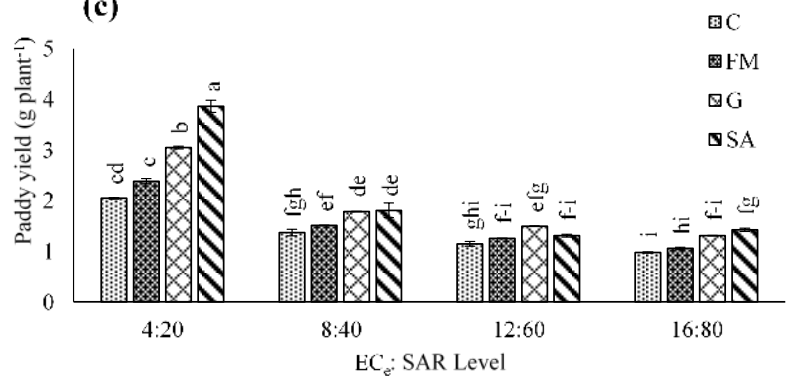

Fig. 2: Effect of $\mathrm{EC}_{\mathrm{e}}$ : $\mathrm{SAR}$ levels and amendments on growth parameters of rice (a) biological yield $\left(\mathrm{g}_{\text {plant }}{ }^{-1}\right),(\mathbf{b})$ plant height $(\mathrm{cm})$ and $(\mathbf{c})$ paddy yield $\left(\mathrm{g} \mathrm{plant}^{-1}\right)$.

$\mathrm{C}=$ Control; $\mathrm{FM}=$ Farm manure at $25 \mathrm{Mg} \mathrm{ha}^{-1} ; \mathrm{G}=$ Gypsum at $100 \%$ SGR; $\mathrm{SA}=$ Sulphuric acid equivalent to $100 \%$ SGR. Bars denote standard error $(n=3)$. Common alphabets above bars represent non-significant difference at $P \leq 0.05$

The highest values for straw and paddy $\mathrm{K}: \mathrm{Na}$ ratio was observed with SA treatment whereas these values decreased as $\mathrm{EC}_{\mathrm{e}}: \mathrm{SAR}$ level increased.

\section{Variation in post-harvest soil chemical properties due to applied amendments at various $\mathrm{EC}_{\mathrm{e}}: \mathrm{SAR}$ levels}

Soil $\mathbf{E C}_{\mathrm{e}}$ : The results showed that amendments and $\mathrm{EC}_{\mathrm{e}}$ :SAR levels had significant $(P \leq 0.05)$ effects on postharvest soil $\mathrm{EC}_{\mathrm{e}}$ (Table 3). Overall, organic and inorganic amendments application decreased soil $\mathrm{EC}_{\mathrm{e}}$ at all $\mathrm{EC}_{\mathrm{e}}: \mathrm{SAR}$ levels whereas, the decrease was more pronounced with $\mathrm{SA}$ and the order of amendments in reclaiming $\mathrm{EC}_{\mathrm{e}}$ was $\mathrm{SA}>\mathrm{G}$ $>\mathrm{FM}>\mathrm{C}$. The maximum relative decrease in post-harvest soil $\mathrm{EC}_{\mathrm{e}}(61.09 \%$ with respect to control) was observed with 
Response of Rice to Varying Salinity/Sodicity of Soil/ Intl J Agric Biol, Vol 26, No 1, 2021

Table 1: Characteristics of soils used for rice cultivation after developing required $\mathrm{EC}_{\mathrm{e}}$ : $\mathrm{SAR}$ levels prior to the experiment

\begin{tabular}{|c|c|c|}
\hline Desired EC e $_{\mathrm{e}}$ SAR & Achieved EC $\mathrm{E}_{\mathrm{e}}$ SAR & $\mathrm{pH}_{\mathrm{s}}$ \\
\hline $4: 20$ & $04.5: 20.42$ & 7.82 \\
\hline $8: 40$ & $07.9: 38.28$ & 8.51 \\
\hline $12: 60$ & 12.4: 60.38 & 8.7 \\
\hline $16: 80$ & $16.0: 80.23$ & 8.81 \\
\hline
\end{tabular}

$\mathrm{EC}_{\mathrm{e}}\left(\mathrm{dS} \mathrm{m}^{-1}\right)$ and SAR $\left(\mathrm{mmol} \mathrm{L}^{-1}\right)^{1 / 2}$

Table 2: Effect of $\mathrm{EC}_{\mathrm{e}}$ : SAR levels and amendments on rice straw and paddy ions content

\begin{tabular}{|c|c|c|c|c|c|c|c|c|c|c|c|}
\hline \multirow[t]{2}{*}{$\mathrm{EC}_{\mathrm{e}}$ : SAR level } & \multirow[b]{2}{*}{ Amendment } & \multicolumn{2}{|c|}{$\mathrm{N}(\%)$} & \multicolumn{2}{|c|}{$\mathrm{P}(\%)$} & \multicolumn{2}{|c|}{$\mathrm{K}(\%)$} & \multicolumn{2}{|c|}{$\mathrm{Na}(\%)$} & \multicolumn{2}{|c|}{$\mathrm{K}:$ Na ratio } \\
\hline & & Straw & Paddy & Straw & Paddy & Straw & Paddy & Straw & Paddy & Straw & Paddy \\
\hline \multirow[t]{4}{*}{$4: 20$} & $\mathrm{C}$ & $0.40 \mathrm{~g}$ & $0.81 \mathrm{~h}$ & $0.05 \mathrm{fg}$ & $0.21 \mathrm{~b}-\mathrm{e}$ & $0.76 \mathrm{ab}$ & $0.25 \mathrm{abc}$ & $0.327 \mathrm{i}$ & $0.050 \mathrm{de}$ & $2.34 \mathrm{c}$ & $5.11 \mathrm{bc}$ \\
\hline & FM & $0.45 \mathrm{e}$ & $0.85 \mathrm{gh}$ & $0.06 \mathrm{e}^{\circ}$ & $0.24 \mathrm{ab}$ & $0.81 \mathrm{a}$ & $0.27 \mathrm{ab}$ & $0.290 \mathrm{ij}$ & $0.059 \mathrm{cde}$ & $2.80 \mathrm{~b}$ & $4.49 \mathrm{~cd}$ \\
\hline & G & $0.50 \mathrm{~d}$ & $0.92 \mathrm{ef}$ & $0.08 \mathrm{c}$ & $0.24 \mathrm{ab}$ & $0.85 \mathrm{a}$ & $0.28 \mathrm{a}$ & $0.307 \mathrm{i}$ & $0.049 \mathrm{de}$ & $2.77 \mathrm{~b}$ & $5.68 \mathrm{ab}$ \\
\hline & SA & $0.52 \mathrm{~cd}$ & $0.96 \mathrm{de}$ & $0.10 \mathrm{~b}$ & $0.26 \mathrm{a}$ & $0.86 \mathrm{a}$ & $0.29 \mathrm{a}$ & $0.240 \mathrm{j}$ & $0.048 \mathrm{e}$ & $3.58 \mathrm{a}$ & $6.23 \mathrm{a}$ \\
\hline \multirow[t]{4}{*}{$8: 40$} & $\mathrm{C}$ & $0.45 \mathrm{e}$ & $0.83 \mathrm{gh}$ & $0.06 \mathrm{e}$ & $0.19 \mathrm{def}$ & 0.51 ef & $0.20 \mathrm{de}$ & $0.477 \mathrm{~g}$ & $0.079 \mathrm{c}$ & $1.07 \mathrm{ef}$ & $2.51 \mathrm{~g}$ \\
\hline & FM & $0.50 \mathrm{~d}$ & $0.88 \mathrm{fg}$ & $0.10 \mathrm{a}$ & $0.22 \mathrm{bcd}$ & $0.62 \mathrm{~cd}$ & 0.22 cde & $0.443 \mathrm{gh}$ & 0.070 cde & $1.40 \mathrm{de}$ & $3.12 \mathrm{efg}$ \\
\hline & G & $0.54 \mathrm{c}$ & $1.00 \mathrm{~d}$ & $0.08 \mathrm{c}$ & $0.23 a b c$ & $0.64 \mathrm{~cd}$ & $0.23 \mathrm{bcd}$ & $0.403 \mathrm{~h}$ & $0.061 \mathrm{cde}$ & $1.61 \mathrm{~d}$ & $3.69 \mathrm{de}$ \\
\hline & SA & $0.61 \mathrm{~b}$ & $1.07 \mathrm{ab}$ & $0.07 \mathrm{~d}$ & 0.20 cde & $0.68 \mathrm{bc}$ & $0.23 \mathrm{bcd}$ & $0.413 \mathrm{~h}$ & 0.066 cde & $1.65 \mathrm{~d}$ & $3.54 \mathrm{ef}$ \\
\hline \multirow[t]{4}{*}{ 12:60 } & $\mathrm{C}$ & $0.51 \mathrm{~d}$ & $0.93 \mathrm{ef}$ & $0.05 \mathrm{gh}$ & $0.19 \mathrm{c}-\mathrm{f}$ & $0.42 \mathrm{fg}$ & $0.18 \mathrm{ef}$ & $0.667 \mathrm{bc}$ & $0.117 \mathrm{~b}$ & 0.64 ghi & $1.57 \mathrm{~h}$ \\
\hline & FM & $0.61 \mathrm{~b}$ & $1.01 \mathrm{~cd}$ & $0.10 \mathrm{~b}$ & $0.14 \mathrm{~g}$ & $0.55 \mathrm{de}$ & $0.20 \mathrm{de}$ & $0.623 \mathrm{cde}$ & $0.080 \mathrm{c}$ & $0.88 \mathrm{fgh}$ & $2.50 \mathrm{~g}$ \\
\hline & G & $0.62 \mathrm{ab}$ & $1.11 \mathrm{a}$ & $0.06 \mathrm{de}$ & $0.20 \mathrm{c}-\mathrm{f}$ & $0.55 \mathrm{de}$ & $0.21 \mathrm{cde}$ & 0.583 ef & $0.071 \mathrm{~cd}$ & $0.95 \mathrm{fg}$ & $2.99 \mathrm{efg}$ \\
\hline & SA & $0.65 \mathrm{a}$ & $1.09 \mathrm{ab}$ & $0.05 \mathrm{f}$ & $0.16 \mathrm{fg}$ & 0.58 cde & 0.22 cde & $0.553 \mathrm{f}$ & $0.074 \mathrm{c}$ & $1.05 \mathrm{ef}$ & $3.05 \mathrm{efg}$ \\
\hline \multirow[t]{4}{*}{ 16:80 } & $\mathrm{C}$ & $0.41 \mathrm{fg}$ & $0.72 \mathrm{i}$ & $0.03 \mathrm{j}$ & 0.20 cde & $0.33 \mathrm{~g}$ & $0.15 \mathrm{f}$ & $0.780 \mathrm{a}$ & $0.210 \mathrm{a}$ & $0.42 \mathrm{i}$ & $0.72 \mathrm{i}$ \\
\hline & FM & $0.43 \mathrm{ef}$ & $0.85 \mathrm{gh}$ & $0.04 \mathrm{i}$ & $0.22 \mathrm{bcd}$ & $0.41 \mathrm{fg}$ & $0.18 \mathrm{ef}$ & $0.713 \mathrm{~b}$ & $0.120 \mathrm{~b}$ & $0.57 \mathrm{hi}$ & $1.53 \mathrm{hi}$ \\
\hline & G & $0.50 \mathrm{~d}$ & $0.99 \mathrm{~d}$ & $0.04 \mathrm{i}$ & 0.17 efg & $0.48 \mathrm{ef}$ & $0.20 \mathrm{de}$ & $0.643 \mathrm{~cd}$ & $0.079 \mathrm{c}$ & $0.75 \mathrm{f}-\mathrm{i}$ & $2.46 \mathrm{~g}$ \\
\hline & SA & $0.51 \mathrm{~cd}$ & $1.06 \mathrm{bc}$ & $0.04 \mathrm{hi}$ & $0.14 \mathrm{~g}$ & $0.51 \mathrm{ef}$ & $0.20 \mathrm{de}$ & $0.590 \mathrm{def}$ & $0.076 \mathrm{c}$ & $0.87 \mathrm{fgh}$ & $2.71 \mathrm{fg}$ \\
\hline
\end{tabular}

Common alphabets in a column followed by values represents non-significant difference at $P \leq 0.05 . \mathrm{C}=\mathrm{Control} ; \mathrm{FM}=\mathrm{Farm}$ manure at $25 \mathrm{Mg}$ ha ${ }^{-1} ; \mathrm{G}=\mathrm{Gypsum}$ at

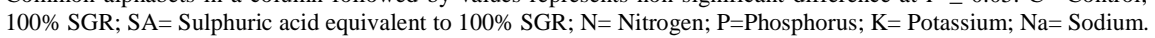

Table 3: Effect of $\mathrm{EC}_{\mathrm{e}}$ : SAR levels and amendments on chemical characteristics of soil

\begin{tabular}{|c|c|c|c|c|c|c|}
\hline $\mathrm{EC}_{\mathrm{e}}$ : SAR level & Amendments & $\mathrm{EC}_{\mathrm{e}}$ & $\mathrm{RP}$ & SAR & $\mathrm{RP}$ & $\mathrm{pH}_{\mathrm{s}}$ \\
\hline $4: 20$ & $\mathrm{C}$ & $3.20 \mathrm{gh}$ & -28.89 & $17.17 \mathrm{~h}$ & -15.85 & $7.58 \mathrm{~cd}$ \\
\hline \multirow{3}{*}{$(4.5: 20.4)^{*}$} & FM & $2.44 \mathrm{hi}$ & -45.85 & $13.83 \mathrm{i}$ & -32.21 & $7.62 \mathrm{c}$ \\
\hline & G & $1.34 \mathrm{ij}$ & -70.23 & $12.98 \mathrm{i}$ & -36.36 & $7.55 \mathrm{cde}$ \\
\hline & SA & $1.25 \mathrm{j}$ & -72.33 & $12.06 \mathrm{i}$ & -40.90 & $7.29 \mathrm{fg}$ \\
\hline $8: 40$ & $\mathrm{C}$ & $6.88 \mathrm{e}$ & -12.95 & $35.34 \mathrm{e}$ & -7.68 & $8.30 \mathrm{~b}$ \\
\hline \multirow{3}{*}{$(07.9: 38.28)^{*}$} & FM & $4.16 \mathrm{fg}$ & -47.31 & $26.76 \mathrm{f}$ & -30.09 & $7.37 \mathrm{efg}$ \\
\hline & $\mathrm{G}$ & $4.37 \mathrm{f}$ & -44.74 & $20.43 \mathrm{~g}$ & -46.64 & $7.38 \mathrm{~d}-\mathrm{g}$ \\
\hline & SA & $3.88 \mathrm{fg}$ & -50.89 & $20.92 \mathrm{~g}$ & -45.34 & $7.33 \mathrm{fg}$ \\
\hline $12: 60$ & $\mathrm{C}$ & $10.69 \mathrm{~b}$ & -13.76 & $52.32 \mathrm{~b}$ & -13.35 & $8.67 \mathrm{a}$ \\
\hline \multirow[t]{3}{*}{$(12.4: 60.38)^{*}$} & FM & $7.81 \mathrm{de}$ & -36.99 & $40.21 \mathrm{~cd}$ & -33.41 & $8.29 \mathrm{~b}$ \\
\hline & $\mathrm{G}$ & $7.30 \mathrm{de}$ & -41.10 & $28.56 \mathrm{f}$ & -52.69 & $7.63 \mathrm{c}$ \\
\hline & SA & $6.77 \mathrm{e}$ & -45.40 & $26.47 \mathrm{f}$ & -56.17 & $7.45 \mathrm{c}-\mathrm{f}$ \\
\hline $16: 80$ & $\mathrm{C}$ & $12.78 \mathrm{a}$ & -20.13 & $70.24 \mathrm{a}$ & -12.45 & $8.62 \mathrm{a}$ \\
\hline \multirow[t]{3}{*}{$(16.0: 80.23)^{*}$} & FM & $9.03 \mathrm{c}$ & -43.58 & $50.77 \mathrm{~b}$ & -36.72 & $8.36 \mathrm{~b}$ \\
\hline & $\mathrm{G}$ & $8.29 \mathrm{~cd}$ & -48.19 & $42.01 \mathrm{c}$ & -47.63 & $7.36 \mathrm{efg}$ \\
\hline & SA & $7.06 \mathrm{e}$ & -55.90 & $38.28 \mathrm{~d}$ & -52.29 & $7.20 \mathrm{~g}$ \\
\hline
\end{tabular}

SA at $\mathrm{EC}_{\mathrm{e}}$ :SAR level 4:20 whereas, at $\mathrm{EC}_{\mathrm{e}}$ :SAR level $16: 80,44.78 \%$ decrease was observed with SA as compared to control.

Soil SAR: A significant $(P \leq 0.05)$ effect of amendments and $\mathrm{EC}_{\mathrm{e}}$ :SAR levels on decreasing soil SAR were noticed. The non-significant difference in $\mathrm{G}$ and SA was observed in decreasing post-harvest soil SAR at $\mathrm{EC}_{\mathrm{e}}: \mathrm{SAR}$ level 4:20, $8: 40$ and 12:60 whereas, at level 16:80, a significantly higher reduction was observed with SA. Overall, the order of amendment in decreasing SAR was $\mathrm{SA}>\mathrm{G}>$ $\mathrm{FM}>\mathrm{C}$ (Table 3$)$.
Soil $\mathbf{p H}_{\mathrm{s}}$ : The significant $(P \leq 0.05)$ changes in soil $\mathrm{pH}_{\mathrm{s}}$ were observed with the studied factors. Results revealed that the application of amendments decreases the soil $\mathrm{pH}_{\mathrm{s}}$. The minimum $\mathrm{pH}_{\mathrm{s}} 7.29,7.33,7.45$ and 7.20 was recorded with SA at level 4:20, 8:40, 12:60 and 16:80, respectively while $\mathrm{pH}_{\mathrm{s}}$ of control was 7.58, 8.30, 8.67 and 8.62 at level 4:20, 8:40, 12:60 and 16:80 respectively (Table 3 ).

\section{Discussion}

The present experiment revealed the beneficial effect of 
applied amendments, i.e., SA, G and FM in decreasing $\mathrm{EC}_{\mathrm{e}}$ $\mathrm{SAR}$ and $\mathrm{pH}_{\mathrm{s}}$, of post-rice harvest soil (Table 3). Application of amendments directly or indirectly increased $\mathrm{Ca}^{2+}$ and $\mathrm{Mg}^{2+}$ in soil solution that possibly replace the $\mathrm{Na}^{+}$ present on exchange sites of soil colloids and reduces the SAR of soil. This replaced $\mathrm{Na}^{+}$came into the soil solution and was effectively removed from the rooting zone along with other soluble salts with the application of good quality water, which ultimately reduced the $\mathrm{EC}_{\mathrm{e}}$ of soil (Gharaibeh et al. 2010; Gonçalo et al. 2020). The role of SA was noticeable in decreasing $\mathrm{EC}_{\mathrm{e}}, \mathrm{SAR}$ and $\mathrm{pH}_{\mathrm{s}}$ of soil (Table 3). Previously considerable decrease in $\mathrm{EC}_{\mathrm{e}}, \mathrm{SAR}$ and $\mathrm{pH}_{\mathrm{s}}$ of soil with SA have been reported by Mahmoodabadi et al. (2013) and Ahmad et al. (2013). The promising effect of SA in reducing SAR individually or in combination with other organic and inorganic amendments was also observed by Mahmoodabadi et al. (2013) and indicates the supremacy of SA over $\mathrm{G}$ in ameliorating sodicity. This might be due to the faster dissolution of lime with acid than the gypsum dissolution (Amezketa et al. 2005).

In the current experiment, improvement in physiological attributes (SPAD, $A, g_{s}$ and $E$ ) with SA were promising compared with other applied amendments but in some treatments, $\mathrm{G}$ also performed good (Fig. 1). Cha-Um et al. (2011) reported a significant positive effect of $G$ and FM on SPAD, $A, g_{s}$ and $E$ of rice plant grown in saltaffected soil. The reaction of SA with soil lime, increase both soluble $\mathrm{Ca}^{2+}$ and $\mathrm{SO}_{4}{ }^{2-}$ (Mace et al. 1999) that play the key role in nullifying salt stress and improving physiological and growth characteristics in various plants (Helmy et al. 2013; Akladious and Mohamed 2018; Hussain et al. 2019; Riffat et al. 2020). The alleviation in rice SPAD, $A, g_{s}$ and $E$ also attributed to improved nutrients uptake, which plays a considerable role in the photosynthetic process, stomatal movement, osmoregulation and enzyme activation (Hasanuzzaman et al. 2018).

Application of amendments significantly increased $\mathrm{N}$, $\mathrm{P}$ and $\mathrm{K}$ contents at all $\mathrm{EC}_{\mathrm{e}}: \mathrm{SAR}$ levels in rice straw and paddy (Table 2). Previous research has also shown that organic and inorganic amendments increase nutrient content (Helmy et al. 2013; Singh et al. 2018; Sardar et al. 2021). Overall, the highest straw and paddy $\mathrm{N}$ and $\mathrm{K}$ contents were observed with SA. However, the response of $\mathrm{P}$ was variable. Shaban et al. (2013) found the highest N, P and K content with SA compared to $\mathrm{G}$ and elemental sulphur in sandy loam soil having $\mathrm{EC}_{\mathrm{e}} 14.8 \mathrm{dS} \mathrm{m}^{-1}$ and SAR 22.9. Such improvements may be due to the lowering of $\mathrm{pH}, \mathrm{EC}_{\mathrm{e}}$ and SAR of the treated soil through amendment addition and improving utilization of essential plant nutrients (Mazhar et al. 2011; Shaban et al. 2013). The synergistic effect of SA on N, P and K availability and uptake was also reported by Helmy et al. (2013). In contrast, it was observed that rice $\mathrm{Na}^{+}$contents significantly decreased with the application of SA. As applied amendments play a significant role in saline-sodic soil reclamation and removal of excessive $\mathrm{Na}^{+}$from root zone and thus reduce the entry of
$\mathrm{Na}^{+}$in plants and consequently increase $\mathrm{K}: \mathrm{Na}$ ratio of a plant (Jedrum et al. 2014).

Plant height, biological yield and paddy yield (Fig. 2) varied significantly at different $\mathrm{EC}_{\mathrm{e}}: \mathrm{SAR}$ levels as well as with different amendments. Similar to our results, many researchers have demonstrated that rice yield decreases with an increase in salt stress (Hussain et al. 2012, 2013; Hakim et al. 2014; Huang et al. 2017). At higher $\mathrm{EC}_{\mathrm{e}}: \mathrm{SAR}$ levels, diminished rice growth attributed to increased salinity and sodicity level than rice threshold limit, that causes osmotic effect and disturb plant ionic status. The reported threshold salinity level for rice ranged 1.9-3.0 dS m${ }^{-1}$ (Grieve et al. 2012) and may decrease the yield greater than $50 \%$ at an $\mathrm{EC}_{\mathrm{e}}$ of $6.65 \mathrm{dS} \mathrm{m}^{-1}$ (Cha-Um et al. 2011) whereas it could grow unaffectedly up to exchangeable sodium percentage level 40 (Abrol and Bhumbla 1979). Hakim et al. (2014) explained the reduction of grain yield under salt stress as excess salts alter the metabolic activities of the cell wall, limiting its elasticity. As a result, the cell wall becomes rigid and reduced the turgor pressure efficiency in cell enlargement.

Rice plant height, paddy yield and biological yield significantly increased with the application of SA, G and FM, whereas, the growth with SA amendment was considerably high (Fig. 2). The superiority of SA might because of its effect on decreasing soil $\mathrm{pH}$, improving soil aggregation and enhancing the availability of certain plant nutrients (Niazi et al. 2001; Kheir et al. 2018). Helmy et al. (2013) credited the improvement in growth parameters to direct and indirect source of $\mathrm{Ca}^{2+}$, that is required for a variety of plant functions, among which appropriate cell division and elongation, enzyme activity and metabolism are primary. Similar results were also reported by Mazhar et al. (2011) and Saqib et al. (2019).

\section{Conclusion}

This research documented two main outcomes. First, among the amendments examined, at lower $\mathrm{EC}_{\mathrm{e}}: \mathrm{SAR}$ levels $(4: 20$, $8: 40$ and 12:60), the responses of sulphuric acid and gypsum were identical, but at higher level (16:80) sulphuric acid was more effective. Secondly, the disturbance in rice photosynthetic rate, stomatal conductance, transpiration rate and total chlorophyll contents due to salinity/sodicity stress were significantly overcomed with sulphuric acid treatment. Moreover, the improvement in $\mathrm{N}$ and $\mathrm{K}$ contents, $\mathrm{K}: \mathrm{Na}$ ratio and biological and paddy yield were significantly consistent with the effectiveness of soil salinity/sodicity ameliorating treatment.

\section{Acknowledgements}

This research work was supported by National Research Program for Universities- Higher Education Commission (HEC), Islamabad, Pakistan (NRPU \# 4926) and HEC Indigenous scholarship program. 


\section{Author Contributions}

AAQ and GM conceptualized, AAQ investigate, statistical analyzed the data, write and prepare original draft, ZR and EAW review and edit the draft.

\section{Conflict of Interest}

Authors declare no conflict of interest.

\section{Data Availability}

The data will be made available on reasonable request to the corresponding author.

\section{Ethics Approval}

Not applicable.

\section{References}

Abbas G, M Amjad, M Saqib, B Murtaza, MA Naeem, A Shabbir, G Murtaza (2021). Soil sodicity is more detrimental than salinity for quinoa (Chenopodium quinoa Willd.): A multivariate comparison of physiological, biochemical and nutritional quality attributes. J Agron Crop Sci 207:59-73

Abbas MK, AS Ali, HH Hasan, RH Ghal (2013). Salt tolerance study of six cultivars of rice (Oryza sativa L.) during germination and early seedling growth. J Agric Sci 5:250-259

Abrol IP, DR Bhumbla (1979). Crop responses to differential gypsum applications in a highly sodic soil and the tolerance of several crops to exchangeable sodium under field conditions. Soil Sci 127:79-85

Ahamed AA, SIM Izzeldin, AMS Abdalla (2019). The effect of irrigation frequency and farmyard manure on salt leaching under saline-sodic soil. Intl J Acad Multidiscipl Res 3:43-49

Ahmad S, A Ghafoor, ME Akhtar, MZ Khan (2013). Ionic displacement and reclamation of saline-sodic soils using chemical amendments and crop rotation. Land Degrad Dev 24:170-178

Akladious SA, HI Mohamed (2018). Ameliorative effects of calcium nitrate and humic acid on the growth, yield component and biochemical attribute of pepper (Capsicum aпnиит) plants grown under salt stress. Sci Hortic 236:244-250

Amezketa E, R Aragues, R Gazol (2005). Efficiency of sulfuric acid, mined gypsum and two gypsum by-products in soil crusting prevention and sodic soil reclamation. Agron J 97:983-989

Ata-Ul-Karim ST, Q Cao, Y Zhu, L Tang, MIA Rehmani, W Cao (2016). Non-destructive assessment of plant nitrogen parameters using leaf chlorophyll measurements in rice. Front Plant Sci 7; Article 1829

Cha-Um S, Y Pokasombat, C Kirdmanee (2011). Remediation of saltaffected soil by gypsum and farmyard manure-Importance for the production of Jasmine rice. Aust J Crop Sci 5:458-465

Day SJ, JB Norton, CF Strom, TJ Kelleners, EF Aboukila (2019). Gypsum, langbeinite, sulfur, and compost for reclamation of drastically disturbed calcareous saline-sodic soils. Intl J Environ Sci Technol $16: 295-304$

FAO (2020). Food and Agriculture Organization of the United Nations. December 2020. http://www.fao.org/faostat/en/\#data/QC

Gharaibeh M, N Eltaif, S Shra'ah (2010). Reclamation of a calcareous saline-sodic soil using phosphoric acid and by-product gypsum. Soil Manage 26:141-148

Gonçalo Filho F, NDS Dias, SRP Suddarth, JF Ferreira, RG Anderson, CDS Fernandes, RBD Lira, MF Neto, CR Cosme (2020). Reclaiming tropical saline-sodic soils with gypsum and cow manure. Water 12:57-69
Grieve CM, SR Grattan, EV Maas (2012). Plant salt tolerance. In: ASCE Manual and Reports on Engineering Practice No. 71 Agricultural Salinity Assessment and Management, $2^{\text {nd }}$ edn., pp:405-459. Wallender WW, KK Tanji (Eds.). ASCE, Reston, Virginia, USA

Hakim MA, AS Juraimi, MM Hanafi, E Ali, MR Ismail, A Selamat, SR Karim (2014). Effect of salt stress on morpho-physiology, vegetative growth and yield of rice. J Environ Biol 35:317-326

Hasanuzzaman M, MHM Bhuyan, K Nahar, M Hossain, JA Mahmud, M Hossen, AAC Masud, M Fujita (2018). Potassium: A vital regulator of plant responses and tolerance to abiotic stresses. Agronomy 8 Article 31

Helmy AM, KH Shaban, MA El-Galad (2013). Effect of gypsum and sulphur application in amelioration of saline soil and enhancing rice productivity. J Soil Sci Agric Eng 4:1037-1051

Huang L, X Liu, Z Wang, Z Liang, M Wang, M Liu, DL Suarez (2017). Interactive effects of $\mathrm{pH}, \mathrm{EC}$ and nitrogen on yields and nutrient absorption of rice (Oryza sativa L.). Agric Water Manage 194:48-57

Hussain M, HW Park, M Farooq, K Jabran, DJ Lee (2013). Morphological and physiological basis of salt resistance in different rice genotypes. Intl J Agric Biol 15:113-118

Hussain M, KH Jang, M Farooq, DJ Lee (2012). Morphological and physiological evaluation of Korean rice genotypes for salt resistance. Intl J Agric Biol 14:970-974

Hussain M, S Ahmad, S Hussain, R Lal, S Ul-Allah, A Nawaz (2018). Rice in saline soils: Physiology, biochemistry, genetics, and management Adv Agron 148:231-287

Hussain SJ, A Masood, NA Anjum, NA Khan (2019). Sulfur-mediated control of salinity impact on photosynthesis and growth in mungbean cultivars screened for salt tolerance involves glutathione and proline metabolism, and glucose sensitivity. Acta Physiol Plantarum 41:1-13

Isaac RA, WC Johson (1976). Determination of total nitrogen in plant tissue. J Assoc Off Anal Chem 59:98-100

Jedrum S, S Thanachit, S Anusontpornperm, W Wiriyakitnateekul (2014). Soil amendments effect on yield and quality of jasmine rice grown on typic natraqualfs, Northeast Thailand. Intl J Soil Sci 9:37-54

Kheir A, M Shabana, M Seleiman (2018). Effect of gypsum, sulfuric acid, nano-zeolite application on saline-sodic soil properties and whea productivity under different tillage types. J Soil Sci Agric Eng 9:829-838

Leogrande R, C Vitti (2019). Use of organic amendments to reclaim saline and sodic soils: A review. Arid Land Res Manage 33:1-21

Liu L, N Petchphankul, A Ueda, H Saneoka (2020). Differences in physiological responses of two oat (Avena nuda L.) lines to sodicalkalinity in the vegetative stage. Plants 9; Article 1188

Mace JE, C Amrhein, JD Oster (1999). Comparison of gypsum and sulfuric acid for sodic soil reclamation. Arid Soil Res Rehabi $13: 171-188$

Mahmoodabadi M, N Yazdanpanah, LR Sinobas, E Pazira, A Neshat (2013). Reclamation of calcareous saline sodic soil with differen amendments (I): Redistribution of soluble cations within the soil profile. Agric Water Manage 120:30-38

Mazhar AAM, MH Mahgoub, NG Abd El-Aziz (2011). Response of Schefflera arboricola L. to gypsum and sulphur application irrigated with different levels of saline water. Aust J Basic Appl Sci 5:121-129

Nam KH, DY Kim, HJ Shin, IS Pack, CG Kim (2018). Changes in the metabolic profile and nutritional composition of rice in response to $\mathrm{NaCl}$ stress. Kor J Agric Sci 45:154-168

Nan J, X Chen, C Chen, MS Lashari, J Deng, Z Du (2016). Impact of flue gas desulfurization gypsum and lignite humic acid application on soil organic matter and physical properties of a saline-sodic farmland soil in Eastern China. J Soil Sedim 16:2175-2185

Niazi BH, M Ahmed, N Hussain, M Salim (2001). Comparison of sand, gypsum and sulphuric acid to reclaim a dense saline sodic soil. Intl $J$ Agric Biol 3:316-318

Qadir M, E Quillerou, V Nangia, G Murtaza, M Singh, RJ Thomas, P Drechsel, AD Noble (2014). Economics of salt-induced land degradation and restoration. Nat Resour Forum 38:282-295 
Qadir et al. / Intl J Agric Biol, Vol 26, No 1, 2021

Quintero JM, JM Fournier, M Benlloch (2007). $\mathrm{Na}^{+}$accumulation in shoot is related to water transport in $\mathrm{K}^{+}$- starved sunflower plants but not in plants with a normal $\mathrm{K}^{+}$status. J Plant Physiol 164:60-67

Rasouli F, AK Pouya, N Karimian (2013). Wheat yield and physicochemical properties of a sodic soil from semi-arid area of Iran as affected by applied gypsum. Geoderma 193:246-255

Riaz F, G Abbas, M Saqib, M Amjad, A Farooq, S Ahmad, MA Naeem, M Umer, MS Khalid, K Ahmed, N Ahmad (2020). Comparative effect of salinity on growth, ionic and physiological attributes of two quinoa genotypes. Pak. J Agric Sci 57:115-122

Riffat A, M Sajid, A Ahmad (2020). Alleviation of adverse effects of salt stress on growth of maize (Zea mays) by sulfur supplementation. Pak $J$ Bot 52:763-773

Saqib AI, K Ahmed, G Qadir, MQ Nawaz, AR Naseem (2019). Enhancing the solubility and reclamation efficiency of gypsum with $\mathrm{H}_{2} \mathrm{SO}_{4}$. Cercet Agron Mold 52:128-140

Saqib ZA, J Akhtar, MA Haq, I Ahmad, HF Bakhat (2012). Rationality of using various physiological and yield related traits in determining salt tolerance in wheat. Afr J Biotechnol 11:3558-3568

Sardar MF, C Zhu, G Bing, HR Ahmad, T Song, H Li (2021). The fate of antibiotic resistance genes in cow manure composting: Shaped by temperature-controlled composting stages. Bioresour Technol 320: Article 124403
Sardar MF, HR Ahmad, MZ Rehman, M Ozturk, V Altay (2018). Absorption of foliar-applied Lead $(\mathrm{Pb})$ in rice (Oryza sativa $\mathrm{L}$.): A hydroponic experiment. Fresen Environ Bull 27:6634-6639

Shaban K, A Helmy, M El-Galad (2013). Role of gypsum and sulphur application in ameliorating saline soil and enhancing rice productivity. Acta Agron Hung 61:303-316

Shahid SA, M Zaman, L Heng (2018). Soil Salinity: Historical perspectives and a world overview of the problem. In: Guideline for Salinity Assessment, Mitigation and Adaptation Using Nuclear and Related Techniques, pp:43-53. Springer, Cham, Switzerland

Singh YP, S Arora, VK Mishra, H Dixit, RK Gupta (2018). Effect of organic and inorganic amendments on amelioration of sodic soils and sustaining rice (Oryza sativa) wheat (Triticum aestivum) productivity. Ind J Agric Sci 88:140-147

US Salinity Lab. Staff (1954). Diagnosis and Improvement of Saline and Alkali Soils. USDA HandBook.60, Washington DC, USA

Zahra SM, A Wahid, N Maqbool, MH Ibrahim (2018). Effect of thiourea on physiological performance of two salt affected rice (Oryza sativa L.) cultivars. Ann Res Rev Biol 27:1-10

Zhou M, X Liu, Q Meng, X Zeng, J Zhang, D Li, J Wang, W Du, X Ma (2019). Additional application of aluminum sulfate with different fertilizers ameliorates saline-sodic soil of Songnen Plain in Northeast China. J Soil Sedim 19:3521-3533 